\title{
A Comparison of Nutritional Profile and Prevalence of Anemia among Rural Girls and Boys
}

\author{
Kaur ${ }^{1}$, I. P. and Kaur ${ }^{2}, \mathrm{~S}$. \\ ${ }^{\mathbf{1}}$ Assoc. Prof., Department of Nutrition \& Dietetics, Govt. College for Girls, Patiala-147001, Punjab, India \\ ${ }^{2}$ Department of Nutrition \& Dietetics, Govt. College for Girls, Patiala-147001, Punjab, India
}

\section{Abstract}

The present study has been conducted to assess the differences in nutritional profile and prevalence of anemia among rural girls and boys. The group comprised of 50 girls and 50 boys aged 16-18 years studying in government schools. Relevant data on general information, dietary information, biochemical investigations, clinical examination, anthropometric measurements and menstruation was collected. The average hemoglobin levels were found to be 8.9 and $10.77 \mathrm{~g} / \mathrm{dl}$ in female and male subjects, respectively and were positively correlated with anthropometric parameters of height, weight and BMI. Fifty per cent of female subjects were suffering from disturbances in menstrual cycle. Clinical signs and ill effects of anemia were common. Consumption of tea was high and diets were inadequate in fruits, vegetables and milk products reflecting deficiencies in energy, protein, fat, iron and B vitamins. Overall female subjects showed poorer nutritional profile and higher prevalence of anemia as compared to male subjects.

KEY WORDS: Hemoglobin, Menstrual Disturbances, Clinical Signs, Food Habits, Dietary Intake

\section{Introduction}

Anemia due to iron deficiency is perhaps the most widespread clinical nutritional deficiency disease in the world today. Nearly 50 per cent of women of reproductive age and 26 per cent of men in the age group of 15-59 years are anemic (ACC / SCN, 1987 and Beard, 2005). The effects of severe anemia are well established, as compromising work performance and health, others are suggested, such as links with immune competence and resistance to infection (ACC/ SCN, 1987). Adolescence is a crucial phase of growth since it offers the second and last chance for the catch up growth in life cycle. Adolescents who eat less than three meals daily tend to have inadequate intakes of nutrients especially iron. Adolescent girls are particularly prone to iron deficiency anemia because of increased demand of iron for hemoglobin, myoglobin and to make up the loss of iron due to menstruation and poor dietary habits (Beard, 2000). Early menarche is also one of the reasons for high prevalence of anemia (Kaur et al, 2005). The present study is conducted to assess the dietary adequacy and prevalence of anemia among rural adolescent girls and boys of 16-18 years.

\section{Methods}

The data for the present study have been collected from 100 students, 50 girls $\& 50$ boys in the age group of 16-18 years belonging to different villages and studying in government senior secondary school, Chanarthal Kalan, district Fatehgarh Sahib, Punjab. Questionnairecum -interview method was used to elicit general and dietary information of the respondents. Assessment of prevalence of 
anemia was done by biochemical investigation of hemoglobin levels. Clinical examination and ill effects of anemia were recorded with the help of a physician. Anthropometric measurements of height, weight and BMI were taken using standard methods of Jelliffe (1966).

\section{Results \& Discussion}

It was observed that majority of the subjects belonged to Sikh community and general category caste wise. $58 \%$ of female subjects and $60 \%$ of male subjects belonged to nuclear families. $60 \%$ female subjects and $48 \%$ male subjects belonged to families with income less than Rs 5000 per month, $28 \%$ of both had family income of Rs. 5000-10000 per month and $12 \%$ of female and $24 \%$ of male subjects belonged to income group of more than Rs 10000 per month. Majority of the subjects had pucca houses and were engaged in farming. Majority were growing green leafy vegetables in their kitchen gardens.

\section{Biochemical Assessment}

Table 1: Mean hemoglobin levels of subjects

\begin{tabular}{|c|c|c|c|c|c|}
\hline \multicolumn{3}{|c|}{ Hemoglobin level, g/dl } & Girls & \multicolumn{2}{|l|}{ Boys } \\
\hline \multicolumn{3}{|c|}{ Mean \pm S. D. } & $8.9 \pm 1.4$ & \multirow{2}{*}{\multicolumn{2}{|c|}{$\frac{10.77 \pm 1.71}{7.5-14}$}} \\
\hline \multicolumn{3}{|c|}{ Hemoglobin Range g/dl } & $6-12$ & & \\
\hline \multicolumn{6}{|c|}{$\begin{array}{l}\text { Table 2: Distribution of subjects according to } \\
\text { category of anemia as per } W H O(1972) \text { classification }\end{array}$} \\
\hline \multirow[t]{2}{*}{ Category } & \multirow{2}{*}{$\begin{array}{l}\text { Hb } \\
\text { level } \\
\text { (g/dl) }\end{array}$} & \multicolumn{2}{|c|}{$\operatorname{Girls}(\mathbf{N}=50)$} & \multicolumn{2}{|c|}{ Boys $(\mathrm{N}=50)$} \\
\hline & & Number & $\%$ & Number & $\%$ \\
\hline Anemic & $<12$ & 49 & 98 & 28 & 56 \\
\hline $\begin{array}{l}\text { Non- } \\
\text { anemic }\end{array}$ & $\geq 12$ & 1 & 2 & 22 & 44 \\
\hline
\end{tabular}

Data in table 1 indicates that blood hemoglobin levels of the female subjects ranged from 6-12 $\mathrm{g} / \mathrm{dl}$ with the mean value of $8.9 \pm 1.46 \mathrm{~g} / \mathrm{dl}$ where as blood hemoglobin of male subjects ranged from $7.5-14 \mathrm{~g} / \mathrm{dl}$ with the mean value of $10.77 \pm 1.71 \mathrm{~g} / \mathrm{dl}$. When compared with WHO (1972) classification, most of the female subjects (98\%) and 56\% of male subjects were anemic with hemoglobin levels less than $12 \mathrm{~g} / \mathrm{dl}$ (Table 2). When compared with NIN (1986) classification, $56 \%$ of the female subjects and $30 \%$ of male subjects were found to be moderately anemic, $18 \%$ of female and $12 \%$ of male subjects were found to be mildly anemic. $10 \%$ of female subjects and $14 \%$ of male subjects were marginally anemic. Only $2 \%$ of female and $44 \%$ of the male subjects belonged to non -anemic category and $14 \%$ of female subjects and none of the male subjects were found to be severely anemic (Table $3)$.

\begin{tabular}{lccccc}
\multicolumn{5}{c}{$\begin{array}{c}\text { Table 3: Distribution of subjects according to the } \\
\text { category of anemia as per } N I N\end{array}$} & $\begin{array}{c}\text { (1986) } \\
\text { classification }\end{array}$ \\
\hline & $\begin{array}{c}\text { Hb level } \\
(\mathrm{g} / \mathrm{dl})\end{array}$ & $\begin{array}{c}\text { Girls } \\
(\mathrm{N}=50)\end{array}$ & $\begin{array}{c}\text { Boys } \\
(\mathrm{N}=50)\end{array}$ \\
\cline { 2 - 7 } Category & $\mathrm{N}$ & $\%$ & $\mathrm{~N}$ & $\%$ \\
\hline $\begin{array}{l}\text { Severely } \\
\text { anemic }\end{array}$ & $\leq 7.0$ & 7 & 14 & -- & -- \\
$\begin{array}{l}\text { Moderately } \\
\text { anemic }\end{array}$ & $8.0-9.9$ & 28 & 56 & 15 & 30 \\
$\begin{array}{l}\text { Mildly anemic } \\
\text { Marginally } \\
\text { anemic }\end{array}$ & $10.0-10.9$ & 9 & 18 & 6 & 12 \\
Non-anemic & $11.0-11.9$ & 5 & 10 & 7 & 14 \\
& $\geq 12.0$ & 1 & 2 & 22 & 44 \\
\hline
\end{tabular}

The results were in accordance with studies conducted by Kumari and Singh (2003), Palta and Gurwara (2003) and Shekhar (2004).

\section{Clinical Assessment}

Table 4. Distribution of subjects according to prevalence of clinical signs of anemia*

\begin{tabular}{lcccc}
\hline \multirow{2}{*}{$\begin{array}{l}\text { Clinical signs } \\
\text { of anemia }\end{array}$} & \multicolumn{2}{c}{ Girls (N=50) } & \multicolumn{2}{c}{ Boys (N=50) } \\
\cline { 2 - 5 } & $\mathrm{N}$ & $\%$ & $\mathrm{~N}$ & $\%$ \\
\hline $\begin{array}{l}\text { Paleness of } \\
\text { skin }\end{array}$ & $\mathbf{3 4}$ & $\mathbf{6 8}$ & 12 & 30 \\
$\begin{array}{l}\text { Pale } \\
\text { conjuctiva }\end{array}$ & 13 & 26 & 12 & 24 \\
$\begin{array}{l}\text { Pigmentation } \\
\text { of nails }\end{array}$ & 27 & 54 & 17 & 34 \\
\hline
\end{tabular}

Clinical signs of skin pallor, pale conjunctiva and pigmentation of nails indicating prevalence of anemia among the subjects were observed (Table 4). $68 \%$ of female subjects and $30 \%$ of male 
subjects depicted skin pallor. $26 \%$ of female and $24 \%$ of male subjects showed pale conjunctiva. Pigmentation of nails was observed in $54 \%$ of female subjects and $34 \%$ of male subjects. Jaishree et al (2001), Gosh et al (2002) and Kumari and Singh (2003) also reported similar results among adolescents.

Table 5: Distribution of subjects according to the ill effects of anemia on health*

\begin{tabular}{lcccc}
\hline \multirow{2}{*}{ Ill effects of anemia } & \multicolumn{2}{c}{ Girls $(\mathrm{N}=50)$} & \multicolumn{2}{c}{ Boys $(\mathrm{N}=50)$} \\
\cline { 2 - 5 } & $\mathrm{N}$ & $\%$ & $\mathrm{~N}$ & $\%$ \\
\hline Weakness & 17 & 34 & 11 & 22 \\
Easy fatigability & 32 & 64 & 16 & 32 \\
Dizziness & 5 & 10 & 1 & 2 \\
Frequent headache & 22 & 44 & 2 & 4 \\
Reduced physical & 25 & 50 & 5 & 10 \\
work capacity & 25 & 50 & 5 & 10 \\
Shortness of breath & 25 & 4 & 2 & 4 \\
Poor appetite & 2 & & & \\
\hline
\end{tabular}

Distribution of subjects according to the ill effects of anemia on health showed that $64 \%$ of female and $32 \%$ of male subjects were suffering from easy fatigability. Frequent headache was reported by $44 \%$ of female subjects and $4 \%$ of male subjects. An equal number of female subjects $(50 \%$ each $)$ showed reduced physical work capacity and shortness of breath while $10 \%$ and $30 \%$ of male subjects, respectively showed reduced physical work capacity and shortness of breath. Loss of appetite was reported by $4 \%$ each of both female and male subjects. Feeling of weakness was reported by $34 \%$ of female and $22 \%$ of male subjects while dizziness was reported by $10 \%$ of female subjects and $2 \%$ of male subjects (Table 5). Tiwari and Seshadri (2000) and Beard (2005) also reported similar ill effects of anemia in adolescent girls.

\section{Anthropometric Data}

Table 6: Mean height and weight of subjects

\begin{tabular}{ccccc}
\hline Parameter & $\begin{array}{c}\text { Girls } \\
(\mathrm{N}=50)\end{array}$ & $\begin{array}{c}\text { NCHS } \\
\text { Standard }\end{array}$ & $\begin{array}{c}\text { Boys } \\
(\mathrm{N}=50)\end{array}$ & $\begin{array}{c}\text { NCHS } \\
\text { Standard }\end{array}$ \\
\hline Height,cm & $\mathbf{1 6 1} \pm 5.45$ & 163 & $170 \pm 3.93$ & 174.33 \\
Weight,kg & $49 \pm 5.60$ & 53.8 & $62 \pm 7.79$ & 61.9 \\
\hline
\end{tabular}

The results of anthropometric measurements revealed that the average height of female and male subjects ranged from 150-170 cm and 162.5-189.0 cm; respectively with mean values of $161.0 \pm 5.45 \mathrm{~cm}$ in female subjects and $170.0 \pm 3.93 \mathrm{~cm}$ in male subjects'. The height was almost comparable to NCHS standards (Table 6).

Average weight of female and male subjects ranged from 38-61 $\mathrm{kg}$ and 51-89 $\mathrm{kg}$ with mean value of $49.0 \pm 5.6 \mathrm{~kg}$ and $62.0 \pm 7.8 \mathrm{~kg}$, respectively. Weight of male subjects was comparable to NCHS standards while results showed lower weight values in female subjects when compared with NCHS values (Table 6).

Table 7. Distribution of subjects as per criteria of BMI (James and Liuizzi, 1988)

\begin{tabular}{lcccccc}
\hline $\begin{array}{l}\text { Category/Presumptive } \\
\text { Diagnosis }\end{array}$ & $\begin{array}{c}\text { BMI } \\
\left(\mathrm{kg} / \mathrm{m}^{2}\right)\end{array}$ & \multicolumn{2}{c}{$\begin{array}{c}\text { Girls } \\
(\mathrm{N}=50)\end{array}$} & \multicolumn{2}{c}{$\begin{array}{c}\text { Boys } \\
(\mathrm{N}=50)\end{array}$} \\
\cline { 2 - 7 } & & $\mathrm{N}$ & $\%$ & $\mathrm{~N}$ & $\%$ \\
\hline $\begin{array}{l}\text { Obese Grade 11 } \\
\text { Obese Grade 1 }\end{array}$ & $\mathbf{3 0}$ & - & - & - & - \\
Normal & $\mathbf{2 5 - 3 0}$ & - & - & - & - \\
Marginal & $18.5-20$ & $\mathbf{2 0}$ & $\mathbf{4 0}$ & $\mathbf{2 8}$ & $\mathbf{5 6}$ \\
Malnutrition & & & & 15 & 30 \\
Mild Malnutrition & $17-18.5$ & 8 & 16 & 2 & 4 \\
$\begin{array}{l}\text { Moderate } \\
\text { Malnutrition }\end{array}$ & $16-17$ & 5 & 10 & - & - \\
Severe Malnutrition & $<16$ & 2 & 4 & - & - \\
\hline
\end{tabular}

Anthropometric data on BMI showed that $40 \%$ of female subjects and $56 \%$ of male subjects had normal BMI values where as $30 \%$ of both female and male 
subjects were mildly malnourished, $10 \%$ of female subjects were under the category of moderate malnutrition and $4 \%$ were severely malnourished. None of the male subjects were moderately or severely malnourished while $10 \%$ had grade 1 obesity (Table 7). Results of BMI were in accordance with the studies conducted by Jaishree et al (2001), Srijaya and Jhansi (2003) and Mishra (2004) on school going adolescents.

\section{Information Regarding Menstruation}

Data in table 8 indicates that majority of the subjects had attained menarche at the age of 13-15 years. It was observed that majority $(78 \%)$ of the subjects had menstrual bleeding period of 3-5 days, very few (4\%) had it for less than 3 days and $18 \%$ had it for more than 5 days.

Table 8: Distribution of female subjects according to age of menarche

\begin{tabular}{|c|c|c|}
\hline \multirow{2}{*}{$\begin{array}{c}\text { Age of menarche } \\
\text { (years) }\end{array}$} & \multicolumn{2}{|c|}{ Girls $(N=50)$} \\
\hline & $\mathbf{N}$ & $\%$ \\
\hline$<12$ & 1 & 2 \\
\hline $12-13$ & 9 & 18 \\
\hline $13-14$ & 18 & 36 \\
\hline $14-15$ & 22 & 44 \\
\hline
\end{tabular}

Table 9: Distribution of female subjects according to type of menstrual disturbances (Sembulingam, 2003)

\begin{tabular}{lcc}
\hline \multirow{2}{*}{ Menstrual disturbance } & \multicolumn{2}{c}{ Girls (N=50) } \\
\cline { 2 - 3 } & $\mathbf{N}$ & \% \\
\hline Amenorrhea & 6 & 12 \\
Menorrahagia & 9 & 18 \\
Oligomenorrhea & 9 & 18 \\
Polymenorrhea & 2 & 4 \\
Dysmenorrhea & 25 & 50 \\
\hline
\end{tabular}

The results showed that $50 \%$ of female subjects had normal menstrual cycle where as the other $50 \%$ were suffering from various menstrual disturbances. Among the latter 50\% was suffering from dysmenorrhea. An equal number (18\% each) were suffering from menorrhagia and oligomenorrhea. 12\% were suffering from amenorrhea with the gap of $1 \frac{1 / 2}{2} 2$ months between two menstrual periods and $4 \%$ subjects were suffering from polymenorrhea. One of the subjects was found to be suffering from both menorrhagia and polymenorrhea in addition to dysmenorrhea (Table 9). Shardha and Matheen (1996), Joseph and Senehlata (1997) and Jain (2005) have reported similar findings among rural and urban girls.

\section{Dietary Assessment}

\section{Food Habits}

It was observed that $70 \%$ of female subjects were lacto-vegetarian, $16 \%$ female and $56 \%$ male subjects were ovalacto-vegetarian and 14\% female and $44 \%$ male subjects were found to have nonvegetarian dietary habits. None of the male subjects was lacto-vegetarian. The general meal pattern showed that majority of subjects consumed 3 major meals, breakfast, lunch and dinner. Only $16 \%$ of the female subjects and $14 \%$ of the male subjects were consuming 2 meals a day, they were missing their breakfast. None of the male subjects and $12 \%$ of female subjects carried packed lunch to school. Consumption of tea was observed to be high among both female and male subjects of the study. Majority of them consumed tea in the evening. $24 \%$ of female and $32 \%$ male subjects took tea with breakfast where as $10 \%$ female and $16 \%$ male subjects took tea with lunch. Higher intake of tea and its consumption along with the meals hinder iron absorption in the body and could be the reason for low hemoglobin levels in the subjects.

\section{Food Intake}

Data on daily intake of different food groups (Table 10) shows that consumption of cereals, pulses, other vegetables, fruits, milk and milk products, 
meat and poultry was inadequate among the subjects which was reflected in their low nutritional profiles. The intake of green leafy vegetables was adequate among male subjects and close to adequate levels in female subjects as consumption of preparations like Saag (mustard leaves and spinach) and methi (fenugreek leaves) was high during the period of survey in winter months. The intake of roots and tubers and sugar and

Table 10: Daily food intake of the subject

\begin{tabular}{|c|c|c|c|c|c|c|}
\hline \multirow[b]{2}{*}{ Food $\operatorname{group}(\mathrm{g})$} & \multicolumn{3}{|c|}{ Girls $(\mathbf{N}=50)$} & \multicolumn{3}{|c|}{ Boys $(\mathrm{N}=50)$} \\
\hline & $\begin{array}{c}\text { Average intake } \\
\text { Mean } \pm \text { S.D }\end{array}$ & $\begin{array}{l}\text { Suggested } \\
\text { intake* }\end{array}$ & $\begin{array}{c}\% \\
\text { adequacy }\end{array}$ & $\begin{array}{c}\text { Average intake } \\
\text { Mean } \pm \text { S.D }\end{array}$ & $\begin{array}{c}\text { Suggested } \\
\text { intake* }\end{array}$ & $\begin{array}{c}\% \\
\text { adequacy }\end{array}$ \\
\hline \multirow{3}{*}{$\begin{array}{l}\text { Cereals } \\
\text { Pulses } \\
\text { Green leafy } \\
\text { vegetables }\end{array}$} & $200 \pm 28.38$ & 300 & 66.66 & $327 \pm 83.76$ & 420 & 77.85 \\
\hline & $28 \pm 11.96$ & 60 & 46.63 & $31 \pm 8.46$ & 60 & 51.67 \\
\hline & $83 \pm 70.41$ & 100 & 83.00 & $102 \pm 86.33$ & 100 & 102.00 \\
\hline Roots \& tubers & $104 \pm 59.34$ & 100 & 104.00 & $113 \pm 50.73$ & 200 & 56.50 \\
\hline $\begin{array}{l}\text { Other } \\
\text { vegetables }\end{array}$ & $25 \pm 24.64$ & 100 & 25.00 & $44 \pm 31.54$ & 100 & 44.00 \\
\hline Fruits & $8 \pm 20.95$ & 100 & 8.00 & $8 \pm 20.44$ & 100 & 8.00 \\
\hline Milk & $272 \pm 117.30$ & 500 & 54.32 & $425 \pm 234.4$ & 500 & 85.00 \\
\hline Meat \& poultry & $0.66 \pm 2.35$ & 50 & 1.32 & $5 \pm 16.85$ & 50 & 10.00 \\
\hline Fats \& oils & $28 \pm 6.52$ & 25 & 112.00 & $40 \pm 8.69$ & 25 & 160.00 \\
\hline $\begin{array}{l}\text { Sugar \& } \\
\text { jaggery }\end{array}$ & $32 \pm 16.48$ & 30 & 106.67 & $29 \pm 5.06$ & 35 & 82.85 \\
\hline
\end{tabular}

*ICMR (2003)

Table 11: Daily nutrient intake of the subjects

\begin{tabular}{|c|c|c|c|c|c|c|}
\hline \multirow[t]{2}{*}{ Nutrient } & \multicolumn{3}{|c|}{ Girls $(\mathbf{N}=\mathbf{5 0})$} & \multicolumn{3}{|c|}{ Boys $(\mathbf{N}=50)$} \\
\hline & $\begin{array}{c}\text { Average intake } \\
\text { Mean } \pm \text { S.D. }\end{array}$ & RDA* & $\begin{array}{c}\text { Per cent } \\
\text { Adequacy }\end{array}$ & $\begin{array}{c}\text { Average intake } \\
\text { Mean } \pm \text { S.D }\end{array}$ & RDA* & $\begin{array}{c}\text { Per cent } \\
\text { Adequacy }\end{array}$ \\
\hline Energy (kcal) & $1647.29 \pm 376.34$ & 2060 & 79.50 & $2128.59 \pm 369.14$ & 2640 & 80.62 \\
\hline Protein (g) & $47.46 \pm 9.80$ & 63 & 75.49 & $69.76 \pm 11.01$ & 78 & 89.43 \\
\hline Total fat(g) & $52.29 \pm 13.09$ & $69 * *$ & 76.15 & $78.20 \pm 12.12$ & $\mathbf{8 8} * *$ & 88.86 \\
\hline Iron (mg) & $22.93 \pm 5.04$ & 30 & 76.66 & $27.43 \pm 4.13$ & $\mathbf{5 0}$ & 54.86 \\
\hline Calcium (mg) & $624.24 \pm 211.50$ & 500 & 122.84 & $1250.7 \pm 88.41$ & 500 & 250.00 \\
\hline Vitamin A $(\mu \mathrm{g})$ & $1034 \pm 637$ & 600 & 172.33 & $1400 \pm 432$ & 600 & 233.30 \\
\hline Thiamine (mg) & $1.49 \pm 0.29$ & 1.0 & 149.00 & $2.06 \pm 0.31$ & 1.3 & 158.12 \\
\hline Riboflavin (mg) & $0.89 \pm 0.48$ & 1.2 & 74.15 & $1.16 \pm 0.52$ & 1.6 & 72.50 \\
\hline Niacin (mg) & $11.26 \pm 1.88$ & 14 & 80.40 & $16.36 \pm 2.11$ & 17 & 96.23 \\
\hline Folic acid $(\mu \mathrm{g})$ & $55.70 \pm 13.05$ & 100 & 55.70 & $75.02 \pm 13.56$ & 100 & 75.00 \\
\hline Vitamin $B_{12}(\mu g)$ & $0.31 \pm 0.007$ & $0.2-1.0$ & 50.00 & $0.51 \pm 0.003$ & $0.2-1.0$ & 83.60 \\
\hline Ascorbic acid (mg) & $98.89 \pm 28.70$ & 40 & 250.00 & $111.72 \pm 22.74$ & 40 & 279.50 \\
\hline
\end{tabular}

jaggery was adequate in female subjects but was inadequate in male subjects. Fruits and meat and poultry group, being expensive were consumed in negligible amounts as most of the subjects belonged to low income groups. Akkamahadevi et al (1998), Kumari and Singh (2003) and Prabhakaran (2003) also revealed inadequate intake of these food groups in adolescents. 


\section{Nutrient Intake}

Table 11 shows data on daily energy and nutrient intake by the subjects'. The average daily intake of energy, protein, total fat, iron, riboflavin, folic acid and vitamin $B_{12}$ were found to be inadequate as compared to recommended dietary allowances (ICMR, 1989). The average intake of calcium, vitamin $\mathrm{A}$, thiamine and ascorbic acid were adequate while that of niacin was marginally inadequate. The inadequate intake of protein, iron, folic acid and vitamin $\mathrm{B}_{12}$ could be linked to high prevalence rate of anemia as these are the elements required for hemoglobin formation. Bains and Mann (2000), Bains et al (2003), Kumari and Singh (2003) and Shekhar (2004) also reported lower intake of these nutrients.

Comparison and interrelationships among various parameters

Table 12: Comparison of anthropometric measurements of different income groups

\begin{tabular}{cccccccccc}
\multicolumn{4}{c}{ measurements of different income groups } \\
\cline { 2 - 9 } $\begin{array}{c}\text { Income } \\
\text { per } \\
\begin{array}{c}\text { month } \\
(\mathrm{Rs})\end{array}\end{array}$ & $\mathrm{N}$ & $\begin{array}{l}\mathrm{Ht} \\
\mathrm{cm}\end{array}$ & $\begin{array}{c}\mathrm{Wt} \\
\mathrm{kg}\end{array}$ & $\begin{array}{l}\mathrm{BMI} \\
\mathrm{kg} / \mathrm{m}^{2}\end{array}$ & $\mathrm{~N}$ & $\begin{array}{c}\mathrm{Ht} \\
\mathrm{cm}\end{array}$ & $\begin{array}{l}\mathrm{Wt} \\
\mathrm{kg}\end{array}$ & $\begin{array}{l}\mathrm{BMI} \\
\mathrm{kg} / \mathrm{m}^{2}\end{array}$ \\
\hline$<5000$ & 30 & 159.8 & 46 & 17.5 & 24 & 169.3 & 58.8 & 20.76 \\
$5000-$ & 14 & 160.3 & 49 & 19.4 & 14 & 170.5 & 61.3 & 21.09 \\
10,000 & 14 & & & & & & & & \\
$>10,000$ & 6 & 161.0 & 53.2 & 20.9 & 12 & 171.3 & 68.6 & 23.08 \\
\hline
\end{tabular}

Table 13: Comparison of hemoglobin levels of different income groups

\begin{tabular}{ccccc}
\hline $\begin{array}{c}\text { Income per } \\
\text { month } \\
(\text { Rs })\end{array}$ & \multicolumn{2}{c}{ Girls $(\mathrm{N}=50)$} & \multicolumn{2}{c}{ Boys $(\mathrm{N}=50)$} \\
\cline { 2 - 5 } & $\mathrm{N}$ & $\begin{array}{c}\text { Mean Hb } \\
(\mathrm{g} / \mathrm{dl})\end{array}$ & $\mathrm{N}$ & $\begin{array}{c}\text { Mean Hb } \\
(\mathrm{g} / \mathrm{dl})\end{array}$ \\
\hline$<5000$ & 30 & 8.84 & 24 & 10.12 \\
$5000-10,000$ & 14 & 9.17 & 14 & 11.79 \\
$>10,000$ & 6 & 9.0 & 12 & 10.90
\end{tabular}

Table 14: Comparison of hemoglobin levels with the prevalence of menstrual disturbances in female subjects

\begin{tabular}{lcc} 
& \multicolumn{2}{c}{ Subjects } \\
\cline { 2 - 3 } $\begin{array}{l}\text { Menstrual } \\
\text { disturbance }\end{array}$ & $\mathrm{N}$ & Mean Hb (g/dl) \\
\hline Normal & 25 & 9.0 \\
Dysmenorrhea & 25 & $\mathbf{8 . 8 3}$ \\
Menorrhagia & 9 & 8.34 \\
Polymenorrhea & 2 & 9.5 \\
Amenorrhea & 6 & 8.6 \\
Oligomenorrhea & 9 & $\mathbf{8 . 8 3}$ \\
\hline
\end{tabular}

16
Table 15: Relationship between hemoglobin levels and various anthropometric measurements

\begin{tabular}{lcc}
\hline $\begin{array}{l}\text { Anthropometric } \\
\text { measurement vs }\end{array}$ & Girls $(\mathrm{N}=50)$ & $\begin{array}{c}\text { Boys }(\mathrm{N}=50) \\
\mathrm{r}\end{array}$ \\
\hline Height $(\mathrm{cm})$ & $+\mathbf{0 . 0 7 2}$ & $+\mathbf{0 . 7 3 2}$ \\
Weight $(\mathrm{kg})$ & $+\mathbf{0 . 2 9 3}$ & $+\mathbf{0 . 3 6 6}$ \\
BMI $\left(\mathrm{kg} / \mathrm{m}^{2}\right)$ & $+\mathbf{0 . 2 8 1}$ & $+\mathbf{0 . 0 7 8}$ \\
\hline
\end{tabular}

The comparative data on anthropometric measurements (Table 12) and biochemical investigations (Table 13) revealed that mean height, weight, BMI and hemoglobin levels of the low income groups were lower than the middle and upper income groups.

The results on comparison between hemoglobin levels and menstrual disturbances (Table 14) revealed that female subjects having normal menstrual cycle had higher hemoglobin levels (9.0 $\mathrm{g} / \mathrm{dl}$ ) than the females with menstrual disturbances $(8.83 \mathrm{~g} / \mathrm{dl})$.

The coefficient of correlation (r) between anthropometric measurements and hemoglobin levels (Table 15) showed that hemoglobin levels were positively correlated with anthropometric parameters of height, weight and BMI.

Table 16: Relationship between hemoglobin levels and food intake

\begin{tabular}{|c|c|c|}
\hline Food group & $\begin{array}{c}\text { Girls }(\mathbf{N}=50) \\
\mathbf{r}\end{array}$ & $\begin{array}{c}\text { Boys }(\mathrm{N}=50) \\
\mathbf{r}\end{array}$ \\
\hline Cereals & +0.641 & +0.692 \\
\hline Pulses & +0.229 & +0.373 \\
\hline $\begin{array}{l}\text { Green leafy } \\
\text { vegetables }\end{array}$ & +0.412 & +0.520 \\
\hline $\begin{array}{l}\text { Milk and milk } \\
\text { products }\end{array}$ & +0.038 & +0.210 \\
\hline \multicolumn{3}{|c|}{$\begin{array}{c}\text { Table 17: Relationship between hemoglobin levels and } \\
\text { nutrient intake }\end{array}$} \\
\hline Nutrients & $\begin{array}{c}\text { Girls (N=50) } \\
\mathbf{r}\end{array}$ & $\begin{array}{c}\text { Boys }(\mathbf{N}=50) \\
\mathbf{r}\end{array}$ \\
\hline Energy & +0.436 & +0.662 \\
\hline Protein & +0.517 & +0.651 \\
\hline Iron & +0.319 & +0.439 \\
\hline Vitamin C & +0.365 & +0.601 \\
\hline Folic acid & +0.017 & +0.224 \\
\hline Vitamin $B_{12}$ & $\begin{array}{r}+0.013 \\
\end{array}$ & $\begin{array}{r}+0.581 \\
\end{array}$ \\
\hline
\end{tabular}

A positive correlation was found between hemoglobin levels and intakes of 
cereals, pulses, green leafy vegetables and milk and milk products (Table 16). The hemoglobin levels were also positively correlated with the intakes of energy, protein, iron, vitamin $\mathrm{C}$, folic acid and vitamin $\mathrm{B}_{12}$ (Table 17).

\section{Conclusion}

The present study shows a positive correlation between hemoglobin levels and anthropometric measurements, food intakes and nutrient intakes. Anthropometric parameters of height, weight, BMI and hemoglobin levels of low income groups are lower than middle and upper income groups. Females with normal menstrual cycle have higher hemoglobin levels than females with menstrual disturbances. Overall females show poorer nutritional profile and higher prevalence of anemia as compared to the males. There is an urgent need for improving overall nutritional status of adolescents through nutrition education, community awareness and supplementation programmes. The need for regular blood tests to check hemoglobin levels is emphasized. Nutrition component needs to be included in the school curriculum.

\section{References}

ACC/SCN 1987. First report on the world nutrition situation.36-39.A report compiled from information available to $\mathrm{UN}$ agencies.

Bains, K. and Maan, S. K. 2000. Sub-clinical iron deficiency - A major factor in reducing physical fitness of young women. Ind. J. Nutr. Dietet. 37: 296-300.

Bains, K., Singh, I. and Kaur, R. 2003. Impact of nutrition education on nutrition of rural adolescent girls belonging to western plain zone of Punjab. J. Res. PAU 40: $126-131$.
Beard, J. L. 2000. Iron requirements in adolescent females. J. Nutr. 130: $440 \mathrm{~S}-442 \mathrm{~S}$.

Beard, J. L. 2005. Maternal iron deficiency anemia: Post partum emotions and cognition. J. Nutr. 135: $267-274$.

Gopalan, C., Ramasastri, B. V. and Balasubramaniam, S. C. 1989. Nutritive value of Indian Foods. 47 - 67. Indian Council of Medical Research, National Institute of Nutrition, Hyderabad, India.

Ghosh, K., Mukherjee, M.B, Shankar, U., Kote, S.L., Nagtilak, S.B., Kolah, R.B., Surve, R.R., Tamankar, A.A., Mohanty, S.S. 2002. Clinical examination and hematological data in asymptomatic apparently healthy school children in a boarding school in a tribal area of Maharashtra. Ind. J. Pub. Health. 46: $61-65$.

ICMR. 1989. Nutrient requirements and recommended dietary allowances for Indians. A report of expert group of Indian Council of Medical Research. 129. National Institute of Nutrition, Hyderabad, India.

ICMR. 2003. Dietary Guidelines for Indians. A manual of Indian Council of Medical Research. 12. National Institute of Nutrition, Hyderabad, India.

Jain, S. 2005. Menstrual disorders in adolescents. Zonal Conference of NOGSI on Adolescence. 23 - 25. Government Medical College, Patiala, India.

Jaishree, P. J., Reddy, S. and Vijaya, N. M. 2001. Nutritional status of school going adolescent girls of Parbhani. Ind. J. Nutr. Dietet. 38: $262-267$.

Jelliffe, D. B. 1966. The assessment of nutritional status of the community. $50-84$. WHO Monograph Series No. 53. Geneva.

Joseph, G. A. and Senehlata. 1997. General and reproductive health of adolescent girls in rural South India. Ind. Pediatr. 34: 243 -251 .

Kaur, P., Kaur, G. and Sarita. 2005. Changing trends and factors affecting age of menarche at Patiala. Zonal Conference of NOGSI on Adolescence. 58. Government Medical College, Patiala, India.

Kumari, S. and Singh, S. 2003. Nutritional status of schedule caste adolescents from deprived section of society. Ind. J. Nutr. Dietet. 40: 147 - 152. 
NCHS. 1987. Anthropometric reference data and prevalence of overweight. $87-88$. US Vital and Health Statistics, Series 11: No. 238.

NIN. 1986. Anemia and endurance capacity. Annual Report. Indian Council of Medical Research. National Institute of Nutrition, Hyderabad, India.

Palta, A. and Gurwara, N. 2003. Hemoglobin and cardiovascular efficiency of adolescent girls. Ind. J. Nutr. Dietet. 40: 327 332.

Prabhakaran, S. 2003. Nutritonal status of adolescent girls residing in a University Hostel. Ind. J. Nutr. Dietet. 40: $274-$ 279.

Shardha, R. V. and Matheen, S. 1996. Nutritional status of adolescent girls and food craving during menstruation. Ind. J. Nutr. Dietet. 33: 266-269.

Shekhar, A. 2004. Current iron status of girls and its effect on work performance. XXXVII Annual National Convention. 103: Indian Dietetic Association, AIIMS, New Delhi, India.

Srijaya, M. and Jhansi, R. P. 2003. Energy balance in selected anemic adolescent girls. Ind. J. Nutr. Dietet. 40: $84-90$.

Tewari, K. and Seshadri, S. 2000. The prevalence of anemia and morbidity profile among school going adolescent girls of urban Kathmandu, Nepal. J. Nep. Med. Assoc. 39: $319-325$.

WHO, 1972. Nutritional anemias. Tech. Rep. Ser. 503: 21. World Health Organisation. Geneva. 